\title{
PRESENTACIÓN
}

\section{Models of Funding, State Institutions and Economic Trends in Universities $\left(14^{\text {th }}-16^{\text {th }}\right.$ Centuries)}

\author{
Modelos de financiación, instituciones estatales y tendencias \\ económicas en las universidades (siglos XIV - XVI)
}

\author{
Hermenegildo FERNANDES" \\ Centro de História, Faculdade de Letras, Universidade de Lisboa \\ ORCID ID: 0000-0003-0760-2429
}

DOI: https://doi.org/10.20318/cian.2021.6155

This thematic issue of CIAN aims to throw new light into one of the most neglected areas in the History of the Universities field, by addressing the general topic of funding in late medieval and early modern Europe in a comparative approach. This will be done through a set of case studies designed to be comprehensive and representative of different models of state building (Iberian kingdoms, France and Papal State) which translate into different ways by which universities connect to polities.

The scope was initially even broader as the huge and loosely connected territory of the Empire should have been represented in this special issue, and will be in a volume that is already being prepared. Unfortunately the pandemic conditions reflected negatively in the preparation resulting in a somewhat shorter version of what had been planned. All the responsibility for that falls necessarily on the organizer and not on the authors or the edi-

\footnotetext{
"Some of the reseach reflected in this paper has been conducted as a part of an FCT funded project CECONOMIA STUDII. Funding, management and resources of the Portuguese University: A comparative analysis ( $13^{\text {th }}-16^{\text {th }}$ centuries $)$, PTDC/EPH-HIS/3154/2014.

**hermenegildo.f@letras.ulisboa.pt
} 
tors of CIAN who all did their best to surpass the inconveniences caused by the pandemic environment.

In this framework two main questions were put to test. Firstly, how contrasting origins reflect on patterns of economic behaviours: does a university controlled by the pope operate in a dissimilar fashion from one that is managed by a monarchy? How do universities operate in a much less centralized political atmosphere like that of the Iberian societies, particularly in the case of the Aragon's crown? Secondly, we tried to assess how and to what extent the funding of universities was impacted by conjuncture. Are there different regional patterns in Europe in this period? Observation will be here framed by the general economic growth in Europe from the mid $15^{\text {th }}$ century onwards after a secular deep economic recession and by the opportunities given by the age of discoveries and by markets operating at a global level. The Spanish and Italian cases will be, regarding this issue, a good point of observation. The case of Lisbon/Coimbra, e.g, the Portuguese medieval university to 1537 , which has been recently already approached in a previous paper published in this journal as well as in other places, was the starting point for this approach, as the reformation of the Studium in the time of D. Manuel is deemed to be directly connected to the economic expansion during the late $15^{\text {th }}$ and early $16^{\text {th }}$.

This special issue has therefore a pre-history that should be acknowledged here. Firstly, considering the larger picture, a lot to the stimulating intellectual research environment derived from the Atelier Heloise and in particular the 8th edition, on the topic "Universities Funding and Management" held in Lisbon the 22, 23 and 24 of October 2018. Discussions concerning the topic continued in following editions held in Leipzig (2019) and Bologna (2021) all of them allowing comparative work that is in the root of this special issue. That approach was particularly important to change the perspective through which the History of the Universities was dealt with, anchoring institutional and cultural History on data basis and prosopographical analysis. In the Portuguese case, particularly, the History of the Universities had been cultivated since the 18th century but with a clear focus on the Portuguese case and little connection to a larger frame. The Atelier Héloïse, but also a by the national agency, FCT, is to blame for the necessary opening. This is in fact the second acknowledgement that should be made here: some of what is being accomplished around the topic of the economy of the university is due to the project CECONOMIA STUDII. Funding, management and resources of the Portuguese university: a comparative analysis (13th-16th centuries), with a team of researchers operating at both national and inter- 
national level (Hermenegildo Fernandes, PI, Armando Norte, co-PI, and also Maria Helena da Cruz Coelho, Hermínia Vasconcelos Vilar and André Oliveira Leitão in the core team, as well as, for instance, Rainer Schwinges as consultant, and Susana Guijarro from the Spanish side). To all of them and to the other researchers in the project this special issue is indebted.

The observation starts with three cases among the main universities in the Papal States, Rome, Perugia and Bologna, arranged here according to a chronological sequence of observation, not of foundation dates.

Carla Frova authors a paper on the financing of the University of Rome, focused on the late Middle Ages, from the foundation bull of Boniface VIII (1303) until 1514 (pontificate of Leo X) in which she discusses a key issue, transversal to some of the cases studies approached here, the relation between the Studium Curie and the Studium Urbis or, to put it more precisely, between an urban and a state model, in this case pontifical, of management and funding. As the chosen chronology clearly states the emphasis is on the later. Frova opposes a XIVth century without a pope in the city, with the management of the university controlled by urban magistrates, and a largely seigneurial model of financing, based on the revenues of a castle, a city, and taxes on the commerce circulating in the Tiber, to the rebirth of the Studium after the return of the popes, with an increasing control by the papal bureaucracy while retaining a certain role to the city's magistrates. A renewal supported by the gabela, the tax on the commerce of wine, a third of which is dedicated to fund the university. Investment in buildings to house the university is connected to this source of revenues although a constant fluctuation due to different papal policies will be in order. The huge investment during the papacy of Leo $\mathrm{X}$, although revealing an abundance of resources previously unequalled not be followed by similar policies in the years to come.

Stefania Zucchini through the case of the Perugia Studium also tests the dichotomy between different sources of power, urban or papal, chronologically divided roughly between the $14^{\text {th }}$ and the early 15 th centuries, in which first municipal and then seigneurial powers are in control, and the period from 1424 onwards when the city becomes part of the papal state that to exert a certain indirect control on the university. One cannot be but stricken with the coincidence of the Roma and Perugia cases at least as far as the government system is concerned and the chronology of change, a fact due to the evolution of general political conjuncture and the building of a papal state with it's own bureaucracy. However in the model of funding some differences can be registered: the Perugia Studium retains for foreign students the ancient Bolognese collecta system, which allows for a total independence of the 
masters from the commune, but in fact is largely based in wages pay through an annual revenue fixed by local authorities. Thus it is possible to observe the level of variation throughout the second half of the $14^{\text {th }}$ and the $15^{\text {th }}$ century. One of the main conclusions deals with conjuncture issues: in spite of the important economic fluctuations, the recession of the $14^{\text {th }}$ century doesn't seem to affect profoundly the university revenues, as the successive powers chose to secure a stable income to allow for payment of wages, mainly. That same stability shows in the amount of these wages, placed between those of the notaries and lower magistrates and the extremely high revenues of the major city's officials like the podestá. All these factors may explain why a career in the university seems to appeal the old oligarchy whose centrality centrally would be stolen by absorption within the papal state.

The oldest university in and outside Italy, Bologna, observed by Maria Teresa Guerrini for the early modern period, may be considered to enrich the register, particularly since in her paper the cases of Roma and Perugia are always in the background. Although Bologna comes into papal control only in the beginning of the 16th century, privileges assigned to the Alma Mater Studiorum almost a century earlier, by Eugenio IV, dealing simultaneously with Roma and Perugia, restructure financially the university assigning the Gabella Grossa tax incomes to fund it. In this sense, and in spite of considerable differences, which allow the University of Bologna a substantial autonomy, if compared with the other case studies, an autonomy completely in line with its tradition and prestige, the papal authority and from the 16th century onwards the papal administration, seems to have managed to create a common ground of management and, mainly, funding, who allowed the universities in the centre and northern Italy to manage through different papal policies and economic crisis. This seems particularly noticeable during the great financial and economic crisis of the $17^{\text {th }}$ century. A comparison with the $14^{\text {th }}$ crisis should constitute an important line of future research, particularly bearing in mind what has been said about the resilience of Roma and Perugia during the long $14^{\text {th }}$ century. Conversely, the signs of crisis in Bologna in the $14^{\text {th }}$ show quite the opposite. Another key issue, directly connected to the economic and social role of the university, relates to the ability to promote social mobility, not necessarily created by the wages, but by both the complementary revenues and symbolic power also related to the access to the rank of nobility and/or closeness to papal administration and provincial court society.

The paper by Jean-Philippe Genet, Thierry Kouamé and Stéphane Lamassé offers an altogether different approach to the Studium Pariensis, one of the few, with Bologna ad Oxford who can trace it's origins before 1200 . 
This, together with the impressive size and institutional complexity, the capacity to attract students from all western Cristianitas, and the connection to the making of the Parisian capitality and contribution to the French kingdom bureaucracy, allows to perceive the Parisian case study as an eventual role model for the evolution of the medieval universities, Bologna being the other. A comprehensive survey of the Studium Parisiensis data basis, developed by the same team, the paper is centred on the colleges as basis for funding and managing academic life, from a social point of view but progressively, as the Middle Ages fades out, as the focal point of teaching activities, until, by the 16th century, all the schools within the University disappear to give way to the Colleges as sole institutional frame. Exploring the database allows firstly getting a firm grasp on the impact of economic and political conjuncture on academic life and funding, almost all the college foundations pre-dating the great crisis of the mid- $14^{\text {th }}$ century. Clear evidence of the great crisis derived from English occupation, during the second quarter of the $15^{\text {th }}$ century is also available in the sources even if we have trouble to identify the stagnation of the number of bursae, a key form of funding the studies of scholars, from 1400 onwards, as a sign of this crisis. Perhaps by this time they had reached an unsurpassable optimum. However, the figures remain impressive and were possible only due to the size of Paris and the ability to recruit all over France and beyond. The limits of this analysis relate to the variable reliability of the sources available: in fact no correlation can be established between the number of bursae and the scholars attested in the Studium belonging to each college (a deviation probably affected by the preservation of the sources, e.g. by a principle of uncertainty). Important variables are the role of convents and religious houses as a decisive part of the University as well as the role of authorship, measured in each of the colleges to cement the symbolic status of the academic community, attracting students and opening careers in royal bureaucracy.

Finally, we must consider the Iberian case study (or case studies). The approach is here conducted by Susana Guijarro by surveying both Castilian and Aragonese universities which offer a great diversity of solutions when dealing with the relation between monarchies and state building processes on one hand (in which I would include episcopate), and urban powers on the other. This tension has a direct result on different models of control and financing that tend to transform medieval Iberia in a laboratory to observe how the universities interact with kings and municipalities in a space strongly influenced by the environment of a frontier society. In the crown of Castile the material basis is guaranteed by the thirds of tithes and there- 
fore constitutes a direct inheritance of the allocation of the income of the dioceses to the war in the frontier with Islam, and can be mobilized in the direction of university foundations when it decreases in intensity. However, urban oligarchies have always had a determining role, as can be seen in the case of Salamanca, in which the Conservatives of the Study are councillors. Thus and without prejudice to the determining role of the central power also in Castile, which incidentally will not be alien to the chronological primacy of the respective Crown, over that of Portugal and Aragon with regard to university foundations, the solution found, which involves the integration of the urban powers in the management of Studia, and the participation of episcopal revenues in their financing, seems to allow to solve some of the blockages that for instance (I will add from my point of view) in Portugal paralyzed the development of the Study, at least in the first two centuries of its existence. In the case of Aragon the function of the urban powers in the foundations and government brings the examples of the crown of Aragon (Lérida, Huesca) closer to the foundations of central and northern Italy. The leading role of cities is in line with everything that is known about the weight of urban oligarchies in that crown, a fact that will always limit the robustness of central power, at least compared to other case studies in Iberia (like the Portuguese case). Two points also, seem to be very specific of the Aragonese case: the evocation of the geographical centrality of Lérida as a reason for choosing the seat of the Catalan study; the difficulty of assuming the political multipolarity of the Crown from the university's point of view, which causes most of the foundations to become frustrated or to materialize in the modern period, even in the most important cities, such as Barcelona.

Some of these issues were elsewhere ${ }^{1}$ put in comparison with the Portuguese case. A princely foundation (D. Dinis, 1288-1290), this one offers, at least from the point of view of the relationship with urban powers and financing, a contrast with the Castilian and Aragonese cases that could not be clearer. In fact, if from the institutional point of view the Portuguese Studium was always under more or less direct patronage from the crown, all the main decisions being made by the king (which includes during the $14^{\text {th }}$ century an successive set of displacements between Lisboa and Coimbra), no specific

${ }^{1}$ A state of the art on the portuguese universiy in CRUZ-COELHO M, FERNANDES H, VILAR H. (2018), "O Studium medieval português: singularidades de um caso periférico". Studia Historica. Historia Medieval [Internet]. 31 Dic 2018 [citado 3 Mar 2019]; 36(2): 83-115 and also in FERNANDES, Hermenegildo; NORTE, Armando; LEITÃO, André de Oliveira. (2016), "Portuguese Studium and Portuguese Scholars in the Middle Ages: Some Remarks on a Research Strand and its Databases", CIAN-Revista de Historia de las Universidades, 19/1 (2016), 27-56. 
funding from royal or local taxes was ever implemented. Instead, revenues from a progressively narrowed list of churches seem to be the main source of funding during the early period, a system that proved to be inefficient by the beginning of the 15th century, mainly because the economic crisis and the harsh devaluation marking the monetary system by that period placed a threat to the survival of this very peripheral Studium. Solutions came through a not entirely successful attempt to connect the funding to ecclesiastical benefices, but mainly through the appointment of a Protector, Infant Henry the Navigator, with huge financial resources at hand, mainly derived from an immense patrimony and from a fair slice in the profits of expansion and commerce in the Atlantic. The pursue of this policy by D. Manuel allowed for an unprecedented growth of the Studium in the beginning of the 16th century. The crown, and not urban elites, who always had a difficult relation with the scholars, saved Portuguese university from the late medieval crisis.

From all these different case studies, in Italy, France and Iberia, one could draw some joint preliminary remarks.

Firstly, the impact of the should be observed from the point of view of the diversity of situations in accessing information but also as a showcase to observe different institutional funding traditions. Thus the processes of building the Archive are not only determined by historical accidents, like the sack of Rome in 1527, but also by different degrees of institutionalization that imply considerable variations in the documents produced within the government of the universities and also among the preservation choices (the example here could be the great differences concerning matriculation registers or expenditure rolls). Connection to the urban government secures production and preservation of registers, like in the case of Perugia, but even in the bigger universities like Paris, the diversity of situations among colleges determines an uncertainty that compromises a precise reconstruction of the academic community. This is even truer in the medieval Iberian universities and particularly in the case of Lisboa/Coimbra, lacking completely for that period matriculation records or accounts.

A second key issue, allowing direct comparison, concerns the sources of income, that is to say, the core model/models of funding. It seems that from these case studies, three different models, not always in complete opposition, may be deducted. The first one uses allocation of commercial and or urban taxes to the funding of the schools that in the case of the papal universities comes to replace by the early 15 th century seigneurial revenues (in Roma, for instance, revenues of a civitas and a castrum and the tax on tiberine fluvial commerce). The other one uses ecclesiastical benefices to 
fund the universities. That had been attempted before the 15 th century but it is with Martin $V$ that it becomes a more widespread practice. That is the case of Bologna but also of the Portuguese university that had been using it, with variable rates of success since the late 13th century. Finally, one cannot minimize the role of the city funding, relevant in the case of Perugia or of the Aragonese universities, a model that must be explained by strong autonomous urban traditions, which powers operating at a larger level, like the kingdoms or the papacy, must accommodate when, throughout the 15th and early 16th century, taking a solid grasp at urban level.

The centrality of the Bursa system, directly connected both to colleges, convents and religious houses, deals with students revenues and support systems, but must not be separated, that is obvious, from the issue of universities' funding. The case study of the Studium Parisiense makes completely intelligible how bursae become a central part of the funding procedures, allowing paying for the master's wages, as colleges progressively become the heart of the academic system.

A third issue, here briefly addressed, derives from the previously stated and concerns a comparative ground of analysis to assert an economic basis for the Homo Academicus social status. A set of data comes from the rich Italian sources. Even if much of the prestige derived from attending or teaching at the university is of symbolic nature and is based both on charisma and social networking, as Pierre Bourdieu has demonstrated through the case study of the French 19th and 20th century Hautes Écoles, the material issues cannot be eluded. As demonstrated in some of the papers professor's wages are not negligible putting some of them between the higher and the lower magistrates in the cities. But the range is very wide and the model of remuneration complex: incomes in Bologna, for instance, include beside the salaries other sources of revenues (private lessons and being part of examination committees). Nevertheless the salaries of professors would form the bulk of the structure of expenditure, like in Roma or Perugia.

The fourth issue is perhaps the key one: conjuncture, or how universities, as long standing institutions survived and dealt with economic cycles, particularly the recession of the lower Middle Ages. Oddly enough one can argue that the degree of exposure seems to be lower than expected. That seems to be the case of Perugia but also of Paris, which manages to stabilize a trend of growth at a high level, stagnation and accommodation replacing in this case recession (relative stagnation in the number of new colleges in Paris reflect closely a conjuncture of crisis after 1360 and also in the first half of the 15th century due to the Hundred Years War). However, an overall movement 
of institutional reform results from the crisis, which accounts for a different behaviour in the $14^{\text {th }}$ and $15^{\text {th }}$ centuries. Relevant results will imply a broader sample and a more precise analysis of several variables: the complex income system of both universities and academic corpora, the evolution in the size of academic staff, the cost of living in each period and city, bearing in mind important regional variations (like Braudel and Spooner demonstrated for the early modern period, the prices of some essential goods like wheat being several times higher in southern Europe than in, for instance, Poland).

A final remark concerns capitality and state building. As above stated many of the examples mirror the relation between urban community and Universitas. Some others are directly connected to royal decree and are closely linked to central control this being the case of most Iberian universities, particularly in Castile but also in Portugal. Overall participation in the processes of state building through an intertwining with royal or papal bureaucracy can be acknowledged in most if not all of case studies. Nevertheless this observation doesn't imply participation in the creation of capitalities. To put it bluntly: most of the cities here documented with universities will not accommodate enough centrality variables to become capitals, political and intellectual protagonism not always matching. Besides the obvious case of Roma, which I think should be put aside, the exception is the case of Paris. As demonstrated in the Paris team paper, the Studium will have a non negligible impact on the consolidation of that capitality. The other case, of course, would be the Portuguese Studium and the role of Lisboa until 1537. 